\title{
ANALISIS PEMAHAMAN KONSEP MATEMATIKA MENGGUNAKAN MEDIA VIDEO PEMBELAJARAN MATEMATIKA DI KELAS III C SDN DEWI SARTIKA CBM
}

\author{
Vanisa Salsabila ${ }^{1}$, Arsyi Rizqia Amalia ${ }^{2}$, Luthfi Hamdani Malula ${ }^{3}$ \\ PGSD FKIP Universitas Muhammadiyah Sukabumi ${ }^{123}$ \\ vanisa.salsabila21107@gmail.com, rizqiaarsyi@gmail.com, \\ luthfihamdani@gmail.com
}

\begin{abstract}
This study aims to describe the analysis of understanding of mathematical concepts using video learning mathematics in class III C SDN Dewi Sartika CBM Sukabumi City. This research uses descriptive qualitative method. Data collection techniques used were interviews and documentation. The researcher acts as an instrument for collecting data. Data analysis techniques using the analysis model according to Miles and Huberman which consists of data reduction, data display, and conclusion drawing / verification. The subjects of this study were all students of class III C in the academic year 2019/2020. The number of students is 28 people. The results showed that students' understanding of mathematical concepts in class III C was quite high, that is, the indicator restated a concept and indicators that were less understood by students, that was, indicators developed the necessary conditions or sufficient conditions of a concept. The obstacles faced by the teacher are not being able to guide students to the fullest, the limitations of students in owning and using mobile phones and parents who cannot spend time working.
\end{abstract}

Keywords: Concept Understanding, Learning Videos, Mathematics

\section{ABSTRAK}

Penelitian ini bertujuan mendeskripsikan analisis pemahaman konsep matematika menggunakan media video pembelajaran matematika di kelas III C SDN Dewi Sartika CBM Kota Sukabumi. Penelitian ini menggunakan metode kualitatif deskriptif. Teknik pengumpulan data yang digunakan adalahh wawancara dan dokumentasi. Peneliti bertindak sebagai instrumen pengumpul data. Teknik analisis data menggunakan model analisis menurut Miles dan Huberman yang terdiri dari tahap reduksi data (data reduction), penyajian data (data display), dan conclusion drawing/verification. Subjek penelitian ini adalah seluruh siswa kelas III C tahun pelajaran 2019/2020. Jumlah siswa sebanyak 28 orang. Hasil penelitian menunjukan bahwa pemahaman konsep matematika siswa kelas III C cukup tinggi yaitu pada indikator menyatakan ulang sebuah konsep dan indikator yang kurang dipahami oleh siswa yaitu indikator mengembangkan syarat perlu atau syarat cukup suatu konsep. Hambatan yang dihadapi oleh guru yaitu tidak dapat membimbing 
siswa secara maksimal, keterbatasan siswa dalam memiliki dan menggunakan handphone serta orang tua yang tidak dapat meluangkan waktu kerja.

Kata Kunci: Pemahaman Konsep, Video Pembelajaran, Matematika

\section{A. Pendahuluan}

Matematika merupakan hal yang penting dalam kehidupan kita, karena disetiap kegiatan kita pasti dikelilingi oleh matematika. Pentingnya matematika harus diajarkan sejak dini, karena semua aspek kehidupan tidak terlepas dari matematika, seperti dalam jual beli suatu produk, menghitung satuan waktu, membangun rumah, mengukur, dan sebagainya.

Maka dari itu, siswa dituntut mampu berpikir kritis, berpikir kreatif, mampu memecahkan masalah dan mampu memahami suatu konsep dalam matematika agar dapat menerapkannya dalam kehidupan sehari-hari. Menurut Masykur \& Fathani (2017: 41) "Matematika, sejak peradaban manusia bermula, memainkan peranan yang sangat vital dalam kehidupan sehari-hari. Berbagai bentuk simbol, rumus, teorema, dalil, ketetapan, dan konsep digunakan untuk membantu perhitungan, pengukuran, penilaian, peramalan, dan sebagainya".
Tujuan

pembelajaran matematika di sekolah dasar, sebagaimana disajikan oleh Depdiknas (dalam Susanto, 2014: 190) salah satunya adalah "memahami konsep matematika, menjelaskan keterkaitan antar konsep, dan mengaplikasikan konsep atau algoritme". Maka dari itu pembelajaran matematika sangatlah penting untuk dapat dipahami, setelah memahami suatu konsep maka selanjutnya menjelaskan keterkaitannya dan mengaplikasikannya dalam pembelajaran. Pemahaman konsep adalah suatu hal yang dapat mempengaruhi hasil belajar pada siswa. Hal ini dikarenakan pemahaman konsep merupakan landasan dalam pembelajaran yang harus dipahami oleh setiap siswa agar materi yang disampaikan dapat diterima dengan baik terutama dalam pembelajaran matematika. Menurut Mawwadah (dalam Unaenah \& Sumantri, 2019: 107) "menyatakan bahwa siswa harus memiliki 
kemampuan pemahaman konsep agar siswa dapat megaplikasikan konsep secara tepat dan efisien dalam proses pembelajaran matematika".

Pada saat ini pendidikan di Indonesia sedang mengalami hambatan dalam pembelajaran, dikarenakan adanya wabah covid-19 (corona virus disaese) yang menyebabkan sekolah-sekolah di Indonesia mengharuskan siswa nya belajar di rumah saja atau belajar secara daring. Pembelajaran yang dilakukan oleh setiap sekolah dan setiap guru mempunyai cara yang berbeda. Cara yang digunakan oleh salah satu guru SDN Dewi Sartika CBM di kelas III C yaitu menggunakan video pembelajaran yang diunggah melaui Youtube kemudian video pembelajaran tersebut dapat dipelajari oleh siswa. Oleh karena itu pemahaman pada siswa akan terasa berbeda dengan pembelajaran tatap muka yang dilakukan seperti biasanya.

Video pembelajaran merupakan media audio visual yang berguna sekali untuk digunakan dalam kondisi pandemi ini, karena dalam video pembelajaran guru dapat menjelaskan materi yang sedang dipelajari oleh siswa seperti guru menjelaskan pembelajaran secara langsung. Hanya saja dalam video pembelajaran guru hanya menjelaskan didepan kamera tanpa ada siswa secara tatap muka. Video pembelajaran diberikan kepada siswa untuk bisa merangsang pemahaman siswa (Jaelani, Darsikin, \& Saehana, 2018: 51). Hal ini menjadikan video pembelajaran dapat merangsang pemahaman siswa karena siswa akan terfokus pada materi yang terdapat di dalam video dan akan memutar ulang video tersebut sampai siswa dirasa sudah memahaminya. Selain itu kedua hal ini sangat penting untuk diteliti karena sejauh mana siswa dapat mehami suatu konsep dalam matematika dengan menggunakan media video pembelajaran dan jarang sekali bagi siswa untuk melakukan pembelajaran menggunakan media video dirumah masing-masing dengan menonton sebuah video atau tanyangan pembelajaran.

\section{B. Metode Penelitian}

Jenis penelitian ini menggunakan metode penelitian deskriptif kualitatif. Teknik pengumpulan data yang digunakan 
yaitu wawancara dan dokumentasi. Teknik analisis data menggunakan model analisis menurut Miles dan Huberman yang terdiri dari tahap reduksi data (data reduction), penyajian data (data display), dan conclusion drawing/verification.

\section{C.Hasil Penelitian dan Pembahasan}

Bloom (dalam Susanto, 2014: 6) "Pemahaman merupakan kemampuan untuk menyerap arti dari suatu materi atau bahan yang dipelajari oleh siswa dengan sebarapa besar siswa mampu menerima, menyerap dan memahami pelajaran yang diberikan oleh guru sampai siswa memahami apa yang dia baca, lihat, alami dan rasakan". Sedangkan menurut Herawati (dalam Sari, 2017: 43) "Siswa harus memahami konsep matematika terlebih dahulu agar dapat menyelesaikan soal-soal dan mampu mengaplikasikan pembelajaran tersebut dalam dunia nyata". Maka dari kedua pernyataan tersebut dikatakan bahwa pemahaman konsep adalah bagaimana siswa mampu menerima, menyerap, dan memahami pelajaran yang diberikan guru serta siswa harus memahami suatu konsep trlebih dahulu agar memudahkan siswa dalam mengerjakan soal-soal.

Media pembelajaran menurut Yaumi (2018: 7) "semua bentuk peralatan fisik yang didesain secara terencana untuk menyampaikan informasi dan membangun interaksi mencakup benda asli, bahan cetak, visual, audio, audio-visual, multimedia dan web. Peralatan tersebut dapat dirancang dan dikembangkan sesuai dengan kebutuhan peserta didik, tujuan pembelajaran serta dapat mengkontruksi pengetahuan dengan efektif dan efisien".

Media pembelajaran yang digunakan adalah media video pembelajaran Busyaeri, Udin, \& Zaenudin (2016: 123) menyatakan bahwa "video sebagai media audiovisual yang menampilkan gerak, semakin lama semakin populer dalam masyarakat. Pesan yang disajikan bisa bersifat fakta maupun fiktif, bisa bersifat informative, edukatif maupun instruksional".

Pemahaman konsep yang dimiliki siswa sangat beragam ketika melakukan pembelajaran menggunakan video pembelajaran, dari yang memahami sampai dengan yang kurang memahami. Tingkat 
Didaktik : Jurnal IImiah PGSD STKIP Subang, ISSN Cetak : 2477-5673 ISSN Online : 2614-722X

Volume VI Nomor 01, Juni 2020

keberhasilan yang dicapai dari tingkat sedang sampai tingkat sangat tinggi. Hambatan yang sangat dikeluhkan adalah kurang dalam membimbing siswa ketika ada siswa yang bertanya mengenai tugas. Upaya yang dilakukan adalah terus berkomunikasi dengan siswa dan orang tua siswa.

Tabel Kategori Nilai Pemahaman Konsep Matematika

\begin{tabular}{|c|c|}
\hline Kategori & Nilai \\
\hline Nilai Tertinggi & 100 \\
\hline Nilai Terendah & 65 \\
\hline Rata-rata & 90,45 \\
\hline$>\mathrm{KKM}(70)$ & $91 \%$ \\
\hline$<\mathrm{KKM}(70)$ & $9 \%$ \\
\hline
\end{tabular}

terdapat nilai tertinggi yang diperoleh siswa dengan nilai 100 dan nilai terendah yang diperoleh siswa dengan nilai 65. Rata-rata nilai siswa secara keseluruhan adalah 90,45 dengan porsentase nilai yang sudah mencapai lebih dai KKM sebesar $91 \%$ dan porsentase nilai yang masih kurang dari KKM sebesar 9\%.

Tabel Tingkat Pemahaman Konsep Siswa

\begin{tabular}{llll}
\hline \multicolumn{1}{c}{ Indikator } & $\begin{array}{c}\text { No } \\
\text { Soal }\end{array}$ & $\begin{array}{c}\text { Tingkat } \\
\text { Keberha } \\
\text { silan }\end{array}$ & \multicolumn{1}{c}{ Arti } \\
\hline $\begin{array}{l}\text { Menyatakan } \\
\text { ulang sebuah } \\
\text { konsep }\end{array}$ & 1 & $100 \%$ & $\begin{array}{l}\text { Sangat } \\
\text { Tinggi }\end{array}$ \\
$\begin{array}{l}\text { Memberi dan } \\
\text { contoh } \\
\text { non contoh } \\
\text { dari konsep }\end{array}$ & & $95 \%$ & $\begin{array}{l}\text { Sangat } \\
\text { Tinggi }\end{array}$ \\
\hline
\end{tabular}

\begin{tabular}{|c|c|c|c|}
\hline $\begin{array}{l}\text { Menyajikan } \\
\text { konsep dalam } \\
\text { berbagai } \\
\text { bentuk } \\
\text { refresentasi } \\
\text { matematis }\end{array}$ & 3 & $81 \%$ & $\begin{array}{l}\text { Sangat } \\
\text { Tinggi }\end{array}$ \\
\hline $\begin{array}{l}\text { Mengembang } \\
\text { kan syarat } \\
\text { perlu atau } \\
\text { syarat cukup } \\
\text { suatu konsep }\end{array}$ & 4 & $54 \%$ & Sedang \\
\hline $\begin{array}{l}\text { Mengklasifika } \\
\text { sikan objek } \\
\text { tertentu } \\
\text { sesuai } \\
\text { dengan } \\
\text { konsepnya }\end{array}$ & 2 & $95 \%$ & $\begin{array}{l}\text { Sangat } \\
\text { tinggi }\end{array}$ \\
\hline $\begin{array}{l}\text { Memanfaatka } \\
\text { n, dan } \\
\text { memilih } \\
\text { prosedur } \\
\text { tertentu }\end{array}$ & 3 & $81 \%$ & $\begin{array}{l}\text { Sangat } \\
\text { Tinggi }\end{array}$ \\
\hline $\begin{array}{l}\text { Mengaplikasi } \\
\text { kan konsep } \\
\text { ke } \\
\text { pemecahan } \\
\text { masalah }\end{array}$ & 5 & $77 \%$ & Tinggi \\
\hline
\end{tabular}

siswa sangat mampu mengerjakan soal pada indikator pertama yaitu menyatakan ulang sebuah konsep dengan tingkat keberhasilan 100\% dan memiliki kemampuan sedang pada indikator keempat dengan tingkat keberhasilan 54\%.

Hambatan

pembelajaran matematika menggunakan media video pembelajaran matematika yaitu keterbatasan guru dalam membimbing siswa, keterbatasan orang tua dalam membimbing anak dikarenakan ketidak terbiasaan, keterbatasan siswa yang tidak memiliki ponsel sendiri dan 
keterbatasan siswa dalam menggunakan aplikasi atau media sosial. Upaya yang dilakukan adalah berkomunikasi sebaik mungkin dengan siswa ataupun orang tuanya.

\section{E. Kesimpulan}

Pada masa pandemi Covid-19 pembelajaran siswa sekolah dasar dialihkan menggunakan sistem daring. Salah satunya menggunakan media video pembelajaran yang diunggah melalui aplikasi Youtube dan membuka forum diskusi serta penugasan melalui WhatsApp. Pemahaman konsep siswa pada pembelajaran matematika materi keliling dan luas persegi dan persegi panjang sudah menunjukan tingkat keberhasilan yang sangat tinggi. Hal tersebut menunjukan bahwa siswa sudah mampu memahami materi yang diberikan dengan menggunakan media video pembelajaran.

Hambatan pembelajaran matematika menggunakan media video pembelajaran yaitu terletak pada keterbatasan guru dalam membimbing siswa, keterbatasan orang tua dalam membimbing anaknya, keterbatasan siswa yang tidak memiliki ponsel sendiri dan keterbatasan siswa dalam menggunakan aplikasi atau media sosial. Upaya yang dilakukan adalah berkomunikasi sebaik mungkin dengan siswa ataupun orang tuanya.

\section{DAFTAR PUSTAKA}

\section{Buku :}

Masykur, M., \& Fathani, A. H. (2017). Mathematical Intelligence. Jogjakarta: Ar-Ruzz Media.

Susanto, A. (2014). Teori Belajar dan Pembelajaran di Sekolah Dasar. Jakarta: Kencana Prenadamedia Group.

Yaumi, M. (2018). Media \& Teknologi Pembelajaran. Jakarta: Prenadamedia Group.

\section{Jurnal :}

Busyaeri, A., Udin, T., \& Zaenudin, A. (2016). Pengaruh Penggunaan Video Pembelajaran Terhadap Peningkatan Hasil Belajar Mapel Ipa Di Min Kroya Cirebon. Al Ibtida: Jurnal Pendidikan Guru MI, 3(1), 116-137.

Jaelani, S., Darsikin, D., \& Saehana, S. (2018). Penerapan Model Pembelajaran Inquiry Berbantuan Video Pembelajaran Dan Tutorial Untuk Meningkatkan Hasil Belajar Fisika Pada Siswa Kelas X SMA Negeri 5 Palu. JPFT (Jurnal Pendidikan Fisika Tadulako Online), 6(1), 50.

Sari, P. (2017). Pemahaman Konsep Matematika Siswa Pada Materi Besar Sudut Melalui Pendekatan 
PMRI. II(1), 41-51.

Unaenah, E., \& Sumantri, M. S.

(2019). Analisis Pemahaman

Konsep Matematis Siswa Kelas 5

Sekolah Dasar Pada Materi

Pecahan. Jurnal Basicedu, 3(1), 106-111. 